\title{
KO GLEDALIŠČE POSTANE NAČIN IZOBRAŽEVANJA
}

Ada Bačar

UTŽO Ajdovščina

\section{POVZETEK}

Študijski krožek za gledališko ustvarjanje pri Univerzi za tretje življenjsko obdobje pod vodstvom mentorice Ade Bačar pripravlja avtorske gledališke predstave. Teme za igre jemljejo iz, neposrednega lokalnega okolja in gledališče postane pot učenja za nastopajoče in občinstvo. Tema vsake predstave obdela posamezen utrip javnega življenja. Jezik je originalno vipavsko narečje. Poleg dramskih predstav so posegli tudi v domačo tradicijo lutkarstva. Prvi slovenski lutkar in prva lutkovna predstava sega na konec 19. stoletja. Glede na vseslovenski pomen so za gledališki jezik uporabili knjižno slovenščino. Gledališče približajo ljudem v malih krajih, vrtcih, šolah, domovih za starejše. Študijski krožek Žar je prejel slovensko priznanje Andragoškega centra Slovenije. Gledališče je neizčrpen vir učenja in osebnostne rasti nastopajočih in občinstva.

Ključne besede: gledališče kot izobraževalna pot, izobraževanje in lokalni razvoj, ustvarjalno učenje, problemsko učenje, učenje z delom, izkustveno izobraževanje

\section{WHEN THEATRE HAS BEEN TURNED INTO EDUCATION - ABSTRACT}

At the Third Age University in Ajdovščina in the Western part of Slovenia Ada Bačar has been leading and directing ŽAR, an older adults' theatre study circle. The study circle has been staging its members' own plays concerned with historical and current topics and events from their immediate local environment. Their playwriting and playing plays have become a way of learning not only for the study circle members themselves, but also for their audiences. Since each of their dramatic topics is related to local phenomena and events, the plays have been written in the original Vipava Valley dialect. In parallel members of the study circle have been drawing upon the local puppet theatre tradition as the very first Slovenian puppet theatre play was staged in this area and can be traced back to the end of the 19th century. The study circle, however. has staged this play in the standard Slovenian language to perform it all over Slovenia. Now, the study circle is performing it in smaller localities, kindergartens, schools, old people's homes. The study circle ŽAR also received an educational award of the Institute of Adult Education of Slovenia.

Keywords: theatre as education, education and local development, creative learning, problem-solving oriented education, learning by doing, experiential learning.

Z vlakom, ki te je peljal skozi vse življenje, si se pripeljal na zadnjo postajo. Pa je to res zadnja postaja? Kaj res ni nikjer tračnic, po katerih bi te vlak odpeljal naprej? Saj imaš zdaj čas. V torbici imaš odločbo o upokojitvi in sam se boš odločal, kakšno bo to novo, zadnje obdobje tvojega življenja.

Če bo tvoja odločitev prava, se boš znašel pred vrati z napisom: Univerza za tretje življenjsko obdobje in imenom društva, ki so si ga člani izbrali ob njegovi ustanovitvi. Sama sem se še isto leto, ko sem se upokojila, pri Andragoškem centru Slovenije vpisala v program usposabljanja za mentorje študijskih krožkov. Seve- da na prošnjo in povabilo Ljudske univerze $\mathrm{v}$ Ajdovščini. Kot učiteljica sem imela za seboj bogato 25-letno izkustvo lutkarstva. Za otroke sem že prej pripravljala lutkovne predstave.

\section{MOI PRVI ŠTUDIJSKI KROŽEK IN LUTKOVNA PREDSTAVA}

Ko sem po usposabljanju v občini organizirala prvi študijski krožek, so mi lutkarske izkušnje vedno bolj živo prihajale pred oči. Študijski krožek se je imenoval »Za srečo staršev in njihovih otrok«. Oblikovala se je krasna skupina in nekatere članice so pripeljale tudi svoje 
otroke. Upravičeno bi lahko rekli, da je bilo to medgeneracijsko izobraževanje: od mene, mentorice in upokojenke, do mladih staršev in najmlajših otrok. Učne teme so se v študijskem krožku s pogovori, predavanji, branjem nizale druga za drugo.

Ker sem bila tudi lutkarica, sem kot krono učenja v študijskem krožku v drugem delu študijskega leta dramatizirala legendo zamejske avtorice iz Beneške Slovenije, Marjete Povasnice (psevdonim), »Ljubica in Arpot $\ll$. Kot del našega študija je skupina pripravljala lutkovno predstavo. Sami smo naredili lutke. Pri pripravah nam je pomagala učiteljica li-

\section{Samozavest je ra- sla in z njo obču- tek, da zmoremo.}

kovnega pouka, po potrebi pa smo k dejavnostim študijskega krožka pritegnili še koga drugega. Ko je bil napisan scenarij, smo se osredotočili na izdelavo kulis. Samozavestno smo se lotili vsega, kar je bilo potrebno. Samozavest v nas je rasla in dobivali smo občutek, da zmoremo, nato, da smo nepremagljivi. Samozavest, zgrajena ob teh prilikah, nam je koristila na vsakem koraku. Izbrali smo ljudske pesmi, ki so skladno s tem, kar bi v študijskem krožku morali spoznati in se naučiti, dopolnjevale vsebino igre. Tako smo se tudi poglobili v prelepe ljudske pravljice in legende ter izbirali take, povezane Z našo učno vsebino. Bile so podlaga za našo igro. Učno snov so dopolnjevale, predvsem pa so članom študijskega krožka ponudile veliko doživljajskega dogajanja. Predstava je znanje povezala s čustvi nastopajočih igralcev, govorcev v lutkovnih vlogah.
V vsebini lutkovne predstave so bile pretkane družinske vloge, odnosi med starši in otroki, med »velikimi« in »malimi« ljudmi. Člani študijskega krožka so veliko več izrazili v igranih vlogah kot v realni situaciji, neposredno v svojem imenu. V predstavo so se študenti zelo vživeli, hkrati pa so pokazali nepričakovane izraze in vsebine. Vsi so se $\mathrm{z}$ novimi vlogami v lutkovni predstavi močno poistovetili in igra je bila zelo uspešna. Na odru so zaživele družinske vloge, zaskrbljeni starši, krivice in radosti, otroški svet.

\section{USTVARJALNOST SE LAHKO PREBUDI KADARKOLI}

S predstavo, ki nam je tako uspela, smo gostovali tudi v Špetru na drugi strani meje. Od tam je bila avtorica legende. Nastopali smo v šolah in vrtcih vse naokoli. Med člani študijskega krožka in menoj kot mentorico so se na poteh po gostovanjih, pred predstavo, med njo in po njej nanizala nova spoznanja, razna doživetja in začetna spoznanja, pridobljena $\mathrm{v}$ študijskem krožku, so se poglobila in utrjevala. V ljudeh so zaživela.

Z lutkovno predstavo smo gostovali v raznih manjših krajih, kamor ne pridejo razna druga večja gledališča. Pri oblikovanju igre, igranju vlog, izkustvih ob nastopih so se učili člani študijskega krožka, od njih pa se je učila množica gledalcev v dvorani. Pustili smo vtise, z novimi stališči in spoznanji smo dosegli gledalce. Iz dvorane so na koncu predstave odhajali obogateni. Učili so se, ne da bi se tega prav zavedali. Dotaknili smo se njihovih čustev in razuma. Prav to, da smo gostovali v majhnih

Poti nazaj za mene kot mentorico ni bilo več. Premagala sem svoje predsodke o starosti. Upokojitev se mi je pokazala kot nov izziv. Gledališko dejavnost sem nadaljevala v študijskih krožkih na Univerzi za tretje življenjsko obdobje. Ko se odločiš za delovanje, naj starost kar počaka. Premagala sem razne osebne dvome in strahove, da sem »že upokojena in morda prestara «a lutkarstvo in gledališče. Spoznala sem, da za igro ni potrebna »prva mladost«, ampak je to neka posebna »žlahtna mladost«, polna življenjskih izkušenj, ljubezni in ustvarjanja. Z ustvarjalnostjo te lahko obsije v kateremkoli življenjskem obdobju. 
krajih, se nam je zdelo pomembno poslanstvo. Ljudje so nas sprejemali kot pozornost in javni dogodek. Tega so deležni bolj redko.

\section{VSEBINO NOVE DRAME ODKRIVAMO MED LJUDMI}

Potem smo v študijskih krožkih pripravljali drobne igre. In končno smo bili zreli za »pravo igro«. Temo sem vzela iz domačega okolja. Poslušala sem, kaj ljudje premlevajo v govoricah. Z dramsko postavitvijo smo se želeli odzvati na neposredno življenje in dogajanje v občini. Pripravili smo veseloigro »Vesela ajdovska tržnica«.

Gledališka igra je bila polna našega resničnega življenja, dogajanja med ljudmi, veselega, pa tudi manj veselega. Naš kraj, njegove posebnosti in navade smo obdelali $\mathrm{v}$ pesmi in besedi. Pisala sem nov scenarij. Skupaj smo si zamislili režijo in pripravljali odrske kulise. Poigrali smo se z EU in EURI, ki smo jih vsak po svoje preračunavali. Člani študijskega krožka in občinstvo naj bi se na humoren način otresli strahov pred novo valuto.

In že je prišlo v občino temnejše, težje obdobje odpuščanja delavcev iz tovarn. Skozi »daljnogled « smo ugledali brezizhodnost, ki ji ni bilo videti konca. Vendar človek je tak, da gre naprej, mora naprej. In smo igro sklenili s svojim prevodom »Hvalnice življenja«. Kdo se je v igri več naučil, člani študijskega krožka in mentorica ali občinstvo ob nastopih, bi težko presodili. Učili smo se vsi skupaj in odganjali sence vsakdana. Z ljudmi smo čutili, da smo skupaj in da vsi iščemo rešitve za naše težave. Sledila so gostovanja. Prisluhnila sem članu naše študijske dramske skupine Žar: » Ni me doma. Vsak večer smo kje drugje ...

Zasledovali smo utrip med ljudmi in govorice $\mathrm{v}$ kraju, kulturne obletnice in dnevne dogodke. In že nas je čakal »naš gorenjski slavček « Simon Gregorčič, nova tema za nov scenarij in dramsko uprizoritev, nove kulise in izziv za režijo. Odločitev ni bila naključna. V gledališki skupini smo iskali nov stik z ljudmi v lokalnem okolju. Za to temo smo se odločili, ko smo poskušali povezati našo gledališko dejavnost s kulturno tradicijo naših krajev. Simon Gregorčič ima med ljudmi na Primorskem posebno mesto. Ko so naše ljudi najhuje teptali italijanski fašisti, jim vzeli jezik in prepovedali kulturo, zaprli vse kulturno-izobraževalne organizacije in nacionalizirali imetje društev, je
Učili smo se vsi skupaj in odganjali sence vsakdana. ljudem budila upanje Gregor-

čičeva pesem »Soča«. Mnoge njegove pesmi so ponarodele in živijo med ljudmi z ustnim prenašanjem. Tema igre je priprava skupine na obisk Gregorčičevega groba, kamor se odpravljajo ob obletnici. V besedilu se pojavljajo šaljive nerodnosti, posebnosti današnjega časa in čustva ljudi.

Na oder ne smemo priklicati le skrbi in težav, naj postane igra tudi globoko kulturno doživetje za igralce in gledalce. $\mathrm{V}$ igri bomo plesali in peli, peli ... Lotili smo se vnetega raziskovanja o Simonu Gregorčiču. Koliko učenja z radostjo je bilo v študijskem krožku, ko smo nežno sestavili njegovo podobo in življenje, polno ljubezni do siromašnih, iskrene, skoraj neslutene ljubezni, skrbi za naše izseljence in še in še. Predstava je uspela. Sledila so gostovanja in občinstvo v dvoranah je z nami pelo, pelo.

\section{UČIJO SE ČLANI ŠTUDIJSKEGA KROŽKA, IGRALCI, UČI SE OBČINSTVO}

Skoraj ne moreš opredeliti, česa vsega so se naučili igralci, člani študijskega krožka, in s čim se je obogatilo občinstvo. Skupaj smo se odločali o vsebinah in temi nove drame, sestavljali in pilili scenarij, pripravljali kulise in razvijali naš estetski čut. Naučili smo se vživljati v občinstvo, opazovali smo okolje in iskali temo, ki bi bila za ljudi v danem trenutku najbolj pomembna. Vprašanja in odgovori. Pogovori in zapisi. 
Naš študij in dejavnost sta neustavljivo tekla dalje. Študijsko skupino so prevevala razna čustva in misli: ponos ob doseženem, samozavest, vedoželjnost in želja, da nadaljujemo.

In že je na naša vrata trkal France Prešeren s svojo Urško in njeno mladostno prevzetnostjo. V študijskem krožku smo raziskali utrip časa, ko si je ljubljanska gospoda prizadevala, da bi se v drži in besedi čim bolj približala nemškutarjem. Seveda smo pazili na pravo mero všečnosti in kritike. V igri smo prikazali občutke in poglede ljudi na glavno me-

Gledališč je bližnjica do izobraževanja. sto, nosilce družbene moči in oblasti. Izrazili bi radi izostren občutek Primorcev za zatiranje in socialne krivice. Razvili so ga skozi zgodovinska obdobja slovenstva na robu, v spopadu s tujci na eni strani in z zgoščeno politično premočjo glavnega mesta na drugi. Koliko smo bili pri tem uspešni, nam je povedal aplavz gledalcev.

\section{LUTKOVNE PREDSTAVE IN PRVI SLOVENSKI LUTKAR AJDOVEC KLEMENČIČ}

Posvetiti smo se želeli malo znanemu odkritju, da je konec 19. stoletja v Ajdovščini deloval prvi lutkar Klemenčič in osnoval prvo slovensko lutkovno gledališče. Raziskali smo vse dosegljive podatke o njem in radi bi ga potegnili iz anonimnosti. Slovenija ima že dolgo tradicijo lutkarstva in prednjači pred drugimi državami. Cenimo svoje bogastvo.

In že smo se znašli v lutkovnem svetu, ki je svet posebne lepote in nežnosti. V začetku si nisem mogla predstavljati, da bodo »moje deklice« (vse so že čez 60 let) prijele v roke lutko in z njo pripovedovale našo čudovito zgodbo. Prej smo nastopali v lokalnem narečju. Zdaj smo se prvič spoprijele $\mathrm{z}$ gledališkim, knjiž- nim jezikom. Koliko naporov! Koliko vaj! In nam je uspelo. $\mathrm{V}$ lutke so zaljubljeni tako otroci kot starejši. Gostujemo v vrtcih, šolah in domovih za starejše, prirejamo javne predstave. Kot da nikoli ne moremo zadovoljiti vsega povpraševanja. Članice študijskega krožka so neumorne. Prenesemo tudi velike napore, delamo s srcem in nam ni težko.

\section{IAVNA PRIZNANJA IN NASTOPI GLEDALIŠKE SKUPINE ŽAR}

Študijski krožek za gledališko dejavnost pri Univerzi za tretje življenjsko obdobje Ajdovščina je iz leta $\mathrm{v}$ leto marljivo delal skladno s svojim študijskim program in novo znanje prelival $\mathrm{v}$ gledališke igre, izvedbe predstav in nastope. Naučili so se še raznih dodatnih spretnosti, si nabrali informacij, tudi če jih na začetku niso pričakovali. Velik del študija sta problemsko učenje (problem oriented learning) in učenje $\mathrm{z}$ delom (learning by doing). Za vsak korak naprej $\mathrm{v}$ snovanju nove igre, pripravah in organizaciji, nastopih, izvedbah s ponovitvami so se člani študijskega krožka učili sproti. Pri vsaki naslednji predstavi so dodajali podrobnosti in nove različice ter tako poglabljali znanje. Tako izobraževanje kot tudi gledališka dejavnost sta jim dajala občutek, da so se z okoljem tesno povezali in da skupnost živi. Sledimo korake ljudi v občini. Največjo in najbolj globoko človeško nagrado dobiš v stiku z ljudmi.

Naši nastopi sežejo tudi prek domačega okolja, Vipavske. Z vsemi igrami smo gostovali v

Spodbudo in potrditev našega dela nam je dajalo tudi to, da smo z vsemi igrami nastopili tudi na Festivalu za tretje življenjsko obdobje v Ljubljani v Cankarjevem domu. Vrhunec priznanja za izbiro prave poti pri našem ustvarjanju in izobraževanju pa je bila nagrada Andragoškega centra Slovenije. 
Kamniku, Domžalah in povsod, kamor so nas povabili.

Dajemo pobudo in zgled, da bi tudi drugje organizirali študijske krožke za gledališko dejavnost in igro vpeli v lokalne razmere, sedanje, pretekle in prihodnje. $Z$ novimi znanstvi širimo zamisel, da je gledališče bližnjica do izobraževanja, da se ustvarjalci in občinstvo spreminjajo, sprejemajo nova stališča in vrednote ter se postopoma globlje zavedajo sebe in svojega kraja.

\section{POGLED V PRIHODNOST}

Tak študijski krožek, kot je naš, nikoli ne konča ne študija ne dela. Odpirajo se nove možnosti, porajajo se nove zamisli, med ljudmi v okolju odkrivamo nove teme, primerne za gledališko predstavo. Vez med nami in okoljem se poglablja, nadaljuje se naše ustvarjanje in študij. Naše predstave so avtorsko delo, nastajajo iz ljudi, iz okolja, in namenjene so tudi najbolj preprostim.

Pred nami je precej zahteven avtorski projekt, ki nas kliče, naj ga ne pustimo na polici. Ne morem si zamisliti, kaj bo z njim, če bomo sploh dobili denar za najnujnejše stroške. Osvojimo temo igre in ji ostanemo zvesti. Preostale skrbi urejamo sproti. Ko bomo na uprizoritvi nove igre na koncu zapeli skupaj z občinstvom, bomo postali eno in težave bodo pozabljene.

Naj vam na koncu kot mentorica študijskega krožka povem, da je gledališče moja ljubezen, polna naporov in ustvarjalnosti pri nastajanju scenarijev in režije, odgovornosti in iskanja možnosti za delo. 